F. Reprod. Fert. (1967) 13, 571-575

BRIEF COMMUNICATION

\title{
THE STORAGE OF FOWL SPERMATOZOA
}

\section{PRELIMINARY RESULTS WITH NEW DILUENTS}

\begin{abstract}
F. VAN WAMBEKE*
Government Research Station for Small Stock Husbandry (Ministry of Agriculture, Belgium); Agricultural Research Administration, Government Agricultural Research Centre, Ghent, Belgium
\end{abstract}

(Received 10th January 1967)

\begin{abstract}
Summary. Semen obtained from Rhode Island Red males was stored for $24 \mathrm{hr}$ at 2 to $5^{\circ} \mathrm{C}$ in two diluents containing skimmed milk. The fertilizing ability of the spermatozoa was tested afterwards in White Leghorn and Rhode Island Red hens and the results showed that fowl spermatozoa could be stored for $24 \mathrm{hr}$ without considerable loss of their fertilizing capacity.
\end{abstract}

Polge (1955) stored fowl semen in a glucose-citrate solution with either milk or thin egg albumen. Promising fertility results (50\%) were obtained after $24 \mathrm{hr}$ storage. Schlindler, Weinstein, Moses \& Gabriel (1955) used synthetic and natural media as diluents and fertility results were poor after $24 \mathrm{hr}$ storage. Lake (1960) used a diluent, calculated to have an osmotic pressure and ionic composition similar to lipid- and protein-free seminal plasma, to which was added fructose. Semen, free of transparent fluid, was stored for $24 \mathrm{hr}$ and $64 \%$ fertility was obtained.

Wilcox \& Shorb (1958), Wilcox \& Shaffner (1958), Wilcox (1958, 1959a, b, 1960), Wilcox \& Wilson (1961) and Wilcox \& Clark (1962) used various modifications of a phosphate buffer with antibiotics and diluted the semen in the ratio of 1 part semen to 9 parts diluent for storage. Afterwards the mixture was centrifuged and the spermatozoa were resuspended in buffer plus fructose, to the original semen volume, before insemination. Sixty to $70 \%$ fertile eggs were obtained during 1 week after insemination when the semen had been stored for $48 \mathrm{hr}$ at $2^{\circ} \mathrm{C}$. Blackwood \& Harris (1960) and Harris, Wilcox \& Shaffner (1961) used a metabolic inhibitor (2-ethyl-5-methyl-benzimidazole) to prolong the life of cock spermatozoa during storage for 5 days, and $75 \%$ fertility was obtained thereafter with washed spermatozoa. Saeki (1960), Wales \& White (1961) and Yamane, Tsukunaga \& Takahashi (1962) suggested that hypertonic diluents were beneficial to the survival of fowl spermatozoa in vitro. Subsequently Hobbs \& Harris (1963a, b) and Harris \& Hobbs (1964) obtained promising results with hypertonic citrate and bicarbonate diluents, although the osmotic pressure of the diluents was different. The object of the

* Present address: Burg. Van Gansberghelaan, 26, Merelbeke, Belgium. 
present study was to investigate new diluents for the storage of fowl semen for $24 \mathrm{hr}$ at 2 to $5^{\circ} \mathrm{C}$. The experiments were conducted from November 1965 to September 1966.

Semen from 8-month-old Rhode Island Red (R.I.R.) males (Commercial, Hubbard Autosex strain) of proven fertility was used throughout these experiments. Two types of hens, White Leghorns (Commercial, Stones strain) and R.I.R. (Hubbard Autosex), in their lst laying year were chosen at random for making tests of fertility. Both males and females were kept in individual cages.

Lorenz (1964) suggested certain procedures for the best technique of collecting, diluting and storing fowl semen in vitro. In the present study semen was collected from fifteen males by a two-man technique (Burrows \& Quinn, 1935 ) and care was taken to minimize contamination with transparent fluid. The pooled semen was transferred to tubes in a water bath $\left(37^{\circ} \mathrm{C}\right)$ and diluted as quickly as possible, usually within $15 \mathrm{~min}$, in either of two diluents (Table $\mathrm{I}$ ). Semen was pipetted into the pre-warmed diluent in stoppered tubes of $10 \mathrm{ml}$

TABLE 1

COMPOSITION OF DILUENTS*

\begin{tabular}{l|c|c}
\hline \multicolumn{1}{c|}{ Stock solutions } & $\begin{array}{c}\text { Diluent } \mathrm{I} \\
(\mathrm{ml})\end{array}$ & $\begin{array}{c}\text { Diluent } 2 \\
(\mathrm{ml})\end{array}$ \\
\hline Skimmed milk & 50 & 20 \\
Sodium glutamate $(0 \cdot 1 \mathrm{~g} / \mathrm{ml})$ & 24 & 20 \\
Sodium citrate $(\mathrm{dihydrate})(0 \cdot 1 \mathrm{~g} / \mathrm{ml})$ & $7 \cdot 7$ & $7 \cdot 7$ \\
Citric acid $(0 \cdot 1 \mathrm{~g} / \mathrm{ml})$ & $0 \cdot 3$ & 1.3 \\
D-Glucose $(0 \cdot 1 \mathrm{~g} / \mathrm{ml})$ & 17 & 20 \\
Egg albumin & - & 10 \\
Ethanol & 0.2 & 0.2 \\
Water (glass-distilled) & 0.8 & 20.8 \\
\hline
\end{tabular}

* Each diluent contained $200 \mathrm{mg}$ dihydrostreptomycin sulphate and $40 \mathrm{mg}$ oxytetracycline hydrochloride $/ 100 \mathrm{ml}$.

capacity ( 1 volume semen to 1 volume diluent) and gently mixed with a stirring rod. The combined volume of semen and diluent never exceeded $3 \mathrm{ml}$. Some tubes were stoppered with cotton wool and others with rubber bungs. The diluted semen was placed in a refrigerator for storage at 2 to $5^{\circ} \mathrm{C}$.

In preparing diluent 1 , the skimmed milk was heated to 90 to $95^{\circ} \mathrm{C}$ (Van Wambeke, 1964) for $10 \mathrm{~min}$, cooled and filtered before adding to the mixture of the appropriate proportions of citrate, citric acid, glutamate and glucose in an Erlenmeyer flask. The oxytetracycline was dissolved in $0.2 \mathrm{ml}$ ethanol and $0.8 \mathrm{ml}$ glass-distilled water and then placed in the diluent which was completed by adding $200 \mathrm{mg}$ streptomycin. For diluent 2, the albumin of freshly laid eggs was homogenized and pipetted into an Erlenmeyer flask after which the glucose, glutamate, citrate and citric acid were added. The skimmed-milk, glass-distilled water and antibiotics were added to give the final volume of $100 \mathrm{ml}$.

The freezing point depression, $\Delta$, of the diluents was determined with an Astell cryoscope and the $\mathrm{pH}$ with a $\mathrm{pH}$ meter 22 (Radiometer, Copenhagen). 
The hens were inseminated as soon as possible with $0 \cdot 10$ to $0 \cdot 12 \mathrm{ml}$ of cool semen after it had been taken from storage. Four groups (ten to fifteen birds each) of White Leghorns and two groups of R.I.R. hens selected from thirtyone birds were inseminated on different days. The semen was deposited deep in the vagina, and in a few cases the utero-vaginal junction was penetrated so that the spermatozoa entered directly into the shell gland. Inseminations were performed in the afternoon and hens with a hard-shelled egg were not inseminated. Fertility results were based on the number of fertile eggs laid from the 2 nd to the 8 th day inclusive after insemination. The eggs were broken out after 3 to 5 days incubation and embryonic development was observed. A hen was classified as fertile when she had laid at least one fertile egg during the 7-day period.

The results, summarized in Tables 2 and 3, show that fowl spermatozoa can be stored for $24 \mathrm{hr}$ without considerable loss of fertility. There was a suggestion of a slight difference between the fertility results obtained from the two strains of hens especially when diluent 1 was used. However, further investigation of this possibility is required.

TABLE 2

PERCENTAGE FERTILE EGGS LAID DURING DAYS 2 TO 6 INGLUSIVE BY HENS INSEMINATED WITH SEMEN STORED IN DILUENT 1 FOR 24 HR AT 2 TO $5^{\circ} \mathrm{C}$

\begin{tabular}{|c|c|c|c|c|c|c|c|}
\hline \multirow[b]{2}{*}{$\begin{array}{c}\text { Breed of hen } \\
\text { and } \\
\text { type of stopper } \\
\text { in storage tube }\end{array}$} & \multirow[b]{2}{*}{ Group } & \multicolumn{3}{|c|}{ All hens } & \multicolumn{3}{|c|}{ Fertile hens } \\
\hline & & $\begin{array}{l}\text { No. } \\
\text { hens }\end{array}$ & $\begin{array}{l}\text { No. } \\
\text { eggs } \\
\text { laid }\end{array}$ & $\begin{array}{c}\text { Percentage } \\
\text { fertile } \\
\text { eggs }\end{array}$ & $\begin{array}{l}\text { No. } \\
\text { hens }\end{array}$ & $\begin{array}{l}\text { No. } \\
\text { eggs } \\
\text { laid }\end{array}$ & $\begin{array}{c}\text { Percentage } \\
\text { fertile } \\
\text { eggs }\end{array}$ \\
\hline $\begin{array}{l}\text { White Leghorn: } \\
\text { rubber bung }\end{array}$ & $\begin{array}{l}1 \\
2 \\
3 \\
4\end{array}$ & $\begin{array}{l}14 \\
10 \\
11 \\
14\end{array}$ & $\begin{array}{l}66 \\
36 \\
51 \\
76\end{array}$ & $\begin{array}{l}76 \\
94 \\
71 \\
92\end{array}$ & $\begin{array}{r}12 \\
10 \\
9 \\
14\end{array}$ & $\begin{array}{l}58 \\
36 \\
45 \\
76\end{array}$ & $\begin{array}{l}86 \\
94 \\
80 \\
92\end{array}$ \\
\hline Total & - & 49 & 229 & 83 & 45 & 215 & 88 \\
\hline $\begin{array}{l}\text { Rhode Island Red: } \\
\text { cotton-wool plug }\end{array}$ & $\begin{array}{l}2 \\
2\end{array}$ & $\begin{array}{l}13 \\
14\end{array}$ & $\begin{array}{l}68 \\
78\end{array}$ & $\begin{array}{l}99 \\
91\end{array}$ & $\begin{array}{l}13 \\
14\end{array}$ & $\begin{array}{l}68 \\
78\end{array}$ & $\begin{array}{l}99 \\
91\end{array}$ \\
\hline Total & - & 27 & 146 & 95 & 27 & 146 & 95 \\
\hline
\end{tabular}

A few W.L. hens failed to become fertilized despite successive inseminations with stored semen. However, when fresh spermatozoa were deposited into their vagina, these hens produced normal fertile eggs. In contrast, the R.I.R. hens were all fertilized. Whether this was due to strain differences or to the insemination technique, remains to be investigated. Insemination procedure appeared to be critical because mid-vaginal inseminations resulted in more infertile W.L. hens than did depositing the semen close to or, perhaps, through the utero-vaginal junction. The R.I.R. hens, which are heavier birds and have larger reproductive organs, were less influenced by the insemination technique; furthermore their rate of lay remained undisturbed. A few W.L. hens stopped laying for different periods, probably on account of the forcible penetration of the utero-vaginal junction (Bobr, Lake, Lorenz, Ogasawara \& Krzanowska, 1965). 
The $\mathrm{pH}$ of the diluents was $6 \cdot 75$ and 6.1 for diluents 1 and 2 respectively. When $0.5 \mathrm{ml}$ of $0.1 \mathrm{M} \mathrm{HCl}$ was added to $10 \mathrm{ml}$ of both diluents 1 and 2 , the $\mathrm{pH}$ was lowered 0.3 and 0.2 units respectively. The $\mathrm{pH}$ of the semen in diluent 1 varied from $7.1(0 \mathrm{hr})$ to $6.65(24 \mathrm{hr})$ during storage in tubes with cottonwool plugs. On the other hand, semen diluted with diluent 2 had an initial $\mathrm{pH}$ of 6.5 and after $24 \mathrm{hr}$ the $\mathrm{pH}$ was 6.45 and 6.25 in tubes with rubber bungs and cotton-wool plugs respectively. These observations agree with the findings of Wilcox (1959a) who showed that fertility was not affected between wide $\mathrm{pH}$ ranges (6.5 to 8 ). However, Wilcox used different conditions of storage. Both diluents were hypertonic to seminal plasma $\left(\Delta-1.1^{\circ}\right.$ for 1 and $-0.98^{\circ}$ for 2) and thus, like Yamane et al. (1962), Hobbs \& Harris (1963a, b) and Harris \& Hobbs (1964), it has been found that spermatozoa can retain their fertilizing capacity in hypertonic media.

\section{TABLE 3}

PERCENTAGE FERTILE EGGS LAID DURING DAYS 2 TO 6 INCLUSIVE BY HENS INSEMINATED WITH SEMEN STORED IN DILUENT 2 FOR 24 HR AT 2 TO $5^{\circ} \mathrm{C}$

\begin{tabular}{|c|c|c|c|c|c|c|c|}
\hline \multirow{2}{*}{$\begin{array}{c}\text { Breed of hen } \\
\text { and } \\
\text { type of stopper } \\
\text { in storage tube }\end{array}$} & \multirow[b]{2}{*}{ Group } & \multicolumn{3}{|c|}{ All hens } & \multicolumn{3}{|c|}{ Fertile hens } \\
\hline & & $\begin{array}{l}\text { No. } \\
\text { hens }\end{array}$ & $\begin{array}{l}\text { No. } \\
\text { eggs } \\
\text { laid }\end{array}$ & $\begin{array}{c}\text { Percentage } \\
\text { fertile } \\
\text { eggs }\end{array}$ & $\begin{array}{l}\text { No. } \\
\text { hens }\end{array}$ & $\begin{array}{l}\text { No. } \\
\text { eggs } \\
\text { laid }\end{array}$ & $\begin{array}{c}\text { Percentage } \\
\text { fertile } \\
\text { eggs }\end{array}$ \\
\hline $\begin{array}{l}\text { White Leghorn: } \\
\text { cotton-wool plug }\end{array}$ & $\begin{array}{l}1 \\
2\end{array}$ & $\begin{array}{l}14 \\
10\end{array}$ & $\begin{array}{l}64 \\
46\end{array}$ & $\begin{array}{l}94 \\
98\end{array}$ & $\begin{array}{l}14 \\
10\end{array}$ & $\begin{array}{l}64 \\
46\end{array}$ & $\begin{array}{l}94 \\
98\end{array}$ \\
\hline Total & - & 24 & 110 & 95 & 24 & 110 & 95 \\
\hline $\begin{array}{l}\text { White Leghorn: } \\
\text { rubber bung }\end{array}$ & $\begin{array}{l}1 \\
2 \\
3 \\
4 \\
1 \\
2\end{array}$ & $\begin{array}{r}14 \\
10 \\
10 \\
15 \\
14 \\
9\end{array}$ & $\begin{array}{l}68 \\
45 \\
51 \\
71 \\
77 \\
41\end{array}$ & $\begin{array}{l}94 \\
93 \\
82 \\
89 \\
92 \\
93\end{array}$ & $\begin{array}{r}14 \\
10 \\
9 \\
15 \\
14 \\
9\end{array}$ & $\begin{array}{l}68 \\
45 \\
45 \\
71 \\
77 \\
41\end{array}$ & $\begin{array}{l}94 \\
93 \\
93 \\
89 \\
92 \\
93\end{array}$ \\
\hline Total & - & 72 & 353 & 92 & 71 & 347 & 92 \\
\hline $\begin{array}{l}\text { Rhode Island Red: } \\
\text { rubber bung }\end{array}$ & $\begin{array}{r}1 \\
1+2 \\
1\end{array}$ & $\begin{array}{l}16 \\
28 \\
15\end{array}$ & $\begin{array}{r}83 \\
144 \\
66\end{array}$ & $\begin{array}{l}89 \\
93 \\
98\end{array}$ & $\begin{array}{l}16 \\
28 \\
15\end{array}$ & $\begin{array}{r}83 \\
144 \\
66\end{array}$ & $\begin{array}{l}89 \\
93 \\
98\end{array}$ \\
\hline Total & - & 59 & 293 & 93 & 59 & 293 & 93 \\
\hline
\end{tabular}

Further research is planned to investigate the precise interrelationship between $\mathrm{pH}$ and osmotic balance. The dilution ratio and storage temperature were chosen arbitrarily. It would be of practical interest to know how much the dilution ratio and storage time could be extended without considerably reducing the fertility. The hens were inseminated with $0 \cdot 10$ to $0.12 \mathrm{ml}$ of stored semen which is equivalent to $0.05 \mathrm{ml}$ of undiluted semen. Insemination with a double dose produced no better fertility, therefore an adequate number of spermatozoa remained viable after $24 \mathrm{hr}$ storage.

\section{REFERENCES}

Blackwood, U. B. \& Harris, G. G., JR (1960) Reversible inhibition of 2.5-alkyl benzimidazoles on chicken sperm. Proc. Soc. exp. Biol. Med. 103, 60. 
Bobr, L. W., Lake, P. E., Lorenz, F. W., Ogasawara, F. X. \& Krzanowska, H. (1965) Inhibition of ovulation in the domestic hen by intrauterine insemination. Poult. Sci. 44, 659.

Burrows, W. H. \& Quins, J. P. (1935) A method of obtaining spermatozoa from the domestic fowl. Poult. Sci. 14, 253.

Harris, G. C., JR \& Hobes, T. D. (1964) The effects of fluid to gas ratio, dilution rate and $\mathrm{CO}_{2}$ level on the fertilizing capacity of chicken spermatozoa stored in carbon dioxide extenders. Poult. Sci. 43, 529.

HARris, G. C., JR, Wilcox, F. H. \& ShaffNer, C. S. (1961) The storage of chicken and turkey spermatozoa by inhibition with 2-ethyl-5-methylbenzimidazole. Poult. Sci. 40, 777.

HoBbs, T. D. \& Harris, G. C., JR (1963a) Effect of freezing point depression and pH on motility and fertility of chicken spermatozoa stored in sodium citrate extenders. Poult. Sci. 42, 254.

HobBs, T. D. \& HaRRIs, G. C., JR (1963b) Effect of freezing point depression and $\mathrm{CO}_{2}$ on motility and fertility of chicken spermatozoa stored in carbon dioxide extenders. Poult. Sci. 42, 388.

LAKE, P. E. (1960) Studies on the dilution and storage of fowl semen. F. Reprod. Fert. 1, 30.

LORENZ, F. W. (1964) Recent research on fertility and artificial insemination of domestic birds. 5th int. Congr. Anim. Reprod. (Trento), 4, 7.

Polge, C. (1955) Artificial insemination in the fowl. Ph.D. thesis, London University.

SAEKI, Y. (1960) Crooked-necked spermatozoa in relation to low fertility in the artificial insemination of fowl. Poult. Sci. 39, 1345.

Schindler, H., Weinstein, S., Moses, E. \& Gabriel, I. (1955) The effect of various diluents and storage times on the fertilizing capacity of cock semen. Poult. Sci. 34, 1113.

Van Wambeke, F. (1964) The use of milk and skim-milk as cock semen diluents. 5th int. congr. Anim. Reprod. (Trento), 4, 682.

Wales, R. G. \& White, I. G. (1961) The viability of fowl spermatozoa in dilute suspension. Aust. $\mathcal{F}$. biol. Sci. 14, 637.

WrLcox, F. H. (1958) The effect of dilution and concentration of chicken semen on fertility. Poult. Sci. 37, 1357.

WILcox, F. H. (1959a) The effect of different hydrogen ion concentrations during storage and at insemination and of added magnesium and potassium on the fertilizing ability of chicken semen. Poult. Sci. 38, 1159.

WILcox, F. H. (1959b) Effect of the addition of carbohydrates after storage on the motility and fertilizing ability of chicken sperm. Poult. Sci. 38, 1162.

WILcox, F. H. (1960) Effect on fertility of temperature, handling methods, Lake's solution and the addition of egg white, egg yolk, and sugars to the diluent used in storing chicken semen. Poult. $S c i .39,459$.

Wilcox, F. H. \& Clark, R. G. (1962) Semen dilution during storage and washing. Poult. Sci. 41, 1091.

Wilcox, F. H. \& Shaffner, C. S. (1958) The effect of different handling methods and added fructose on the fertilizing ability of chicken spermatozoa after storage. Poult. Sci. 37, 1353.

WrLcox, F. H. \& SHORв, M. S. (1958) The effect of antibiotics on bacteria in semen and on motility and fertilizing ability of chicken spermatozoa. Am.J. vet. Res. 19, 945.

Wircox, F. H. \& WiLson, H. R. (1961) The effect of the addition of potassium, magnesium and chloride ions to the diluent used in storing chicken semen. Poult. Sci. 40, 701.

Yamane, J., Tsukunaga, S. \& Takahashi, T. (1962) A basic principle of make-up of the dilutor for fowl semen. Zootec. Vet. 17, 523. 